\title{
Article
}

\section{Mycorrhizal fungi status in organic farms of south Florida}

\author{
Toprak $B^{1 *}$, Soti $P^{2}$, Jovel $E^{3}$, Alverado $L^{3}$ and Jayachandran $K^{4}$ \\ ${ }^{1}$ Duzce University, Faculty of Forestry, Duzce, Turkey \\ ${ }^{2}$ Agroecology and Resilient Food Systems, University of Texas Rio Grande Valley, Edinburg TX \\ ${ }^{3}$ Universidad Nacional de Agricultura, Catacamas, Honduras \\ ${ }^{4}$ Department of Earth and Environment, Florida International University, Miami FL
}

Toprak B, Soti P, Jovel E, Alverado L, Jayachandran K 2017 - Mycorrhizal fungi status in organic farms of south Florida. Mycosphere 8(7), 951-958, Doi 10.5943/mycosphere/8/7/10

\begin{abstract}
In the recent years, low input agriculture has gained high popularity and there is an emerging body of literature on the role of arbuscular mycorrhizal fungi in organic farming and its potential use in low input agriculture systems. This study was conducted to analyse mycorrhizal status of several 31 different plants in organically managed farms in south Florida: organic farm at the Florida International University and the organic fruit, farm Possum Trot. Rhizosphere soil was analysed for mycorrhizal spores and soil nutrients, and plant roots were analysed for mycorrhizal colonization status. Possum Trot, which is a less disturbed site, had higher mycorrhizal spore density in the soil as compared to the organic farm at the Florida International University, which gets highly disturbed with student activities. However, plants at the Florida International University organic farm had higher degree of mycorrhizal colonization in the roots. Of the 31-plant species analysed, Cymbopogen nardus had highest root colonization (75\%), while Spinacia oleracea had no signs of mycorhrizal colonization in the roots. Surprisingly, although very low, arbuscular mycorrhizal colonization was observed in roots of Eruca sativa and Chrysophyllum cainito which are normally reported as non-host plants of mycorrhizal fungi. Arbuscular mycorrhizal spore density showed a negative correlation with soil N, while it had a positive correlation with soil $\mathrm{P}$. Though spores of Glomus, Gigaspora, Acaulospora and Scutellospora were found in our study. Glomus were the dominant genera in the rhizosphere of plants grown in the organic farms. Our results indicate that disturbance did not have much impact on the mycorrhizal colonization in the roots, but did have an impact on the rhizosphere spore density. The high occurrence of mycorrhizal fungi in the organic farms of south Florida and potential for the use in organic farm management is discussed.
\end{abstract}

Key words - disturbance - mycorrhizal fungi - organic farms - soil nutrients - sustainable agriculture

\section{Introduction}

Mycorrhiza is one of most important symbiotic relationships between microorganisms and plants (Smith \& Read 1997, Paszkowski 2006). It has positive effects on the growth and production of plants in agroecosystems, as well as wild areas by increasing the supply of soil nutrients (Smith \& Read 2008). There is an emerging body of literature on the role of arbuscular mycorrhizal (AM) fungi in organic farming and its potential use in low input agriculture systems. AM fungi may proliferate 
plant growth by enhancing competitive ability of the host plant (Daisog et al. 2012), enhancing tolerance to soil pathogens (Lendzemo et al. 2005), increasing protection from herbivores and abiotic stress (Bennett et al. 2009) and improving the soil structure (Smith \& Read 1997, Wilson et al. 2009). It is widely acknowledged that the main advantage of mycorrhizal fungi to the host plant is the increased uptake of P, N, K, Zn, Cu, S, Fe, Mg, Ca and Mn (Marschner \& Dell 1994, Clark \& Zeto 2000). Mycorrhizal fungi are known to have a wide variation and adaptation to several soil conditions. They colonize a large number of plant species and lack host-specificity (Lee et al. 2013). However, association of mycorrhizal fungi to the host plant varies significantly across ecological regions depending on the soil properties (Brundrett 1991, Soti et al. 2015) and farm management (Oehl et al. 2004).

South Florida climate offers the opportunity to successfully produce a wide variety of tropical and subtropical fruits and vegetables. However, south Florida's mostly sandy soil with high $\mathrm{pH}$ and low nutrients creates a challenge to the farmers. Understanding the mycorrhizal status of plants in the farm may help in better management of farms and improve productivity to organic growers who have limited soil amendment options (Nelson \& Janke 2007). The objective of this study was to document the mycorrhizal status of different plant species in two different organic farms in south Florida with different levels of disturbances and plant diversity.

\section{Materials \& Methods}

\section{Study site}

The study site is located near the North Atlantic Ocean of Miami, FL, USA. Fieldwork was

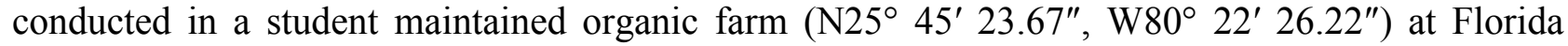

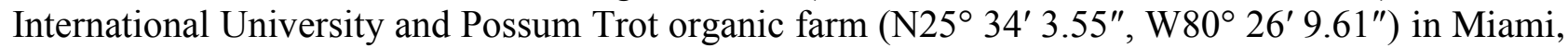
Florida. Miami has a tropical monsoon climate with an average annual rainfall of $1575 \mathrm{~mm}$ and a mean annual temperature of $25^{\circ} \mathrm{C}$.

\section{Sampling}

Rhizosphere soil samples and root samples were collected from 31 plant species in both the farms. The selected plant species and sites of sample collection are given in Table 1. The soil samples were passed through a 2-mm sieve and a portion of soil sample was air dried for the analysis of chemical and physical properties, remaining soil was stored in a $4^{\circ} \mathrm{C}$ fridge for biological analysis.

\section{Measurements}

Forty-five $1.5 \mathrm{~cm}$ root fragments were collected from each plant, and the AM colonization was quantified following a modified method described by McGonigle et al. (1990). Roots were cleared in $15 \% \mathrm{KOH}$ at $70^{\circ} \mathrm{C}$ for 4 hours, rinsed twice with water, bleached with ammoniated $\mathrm{H}_{2} \mathrm{O}_{2}$, and acidified with $1 \mathrm{~N} \mathrm{HCl}$. Root staining was done using Trypan blue in acidified glycerol at $80^{\circ} \mathrm{C}$ for 20 minutes. The stained roots were then examined with a dissecting microscope at 30-60 X magnification for the degree of mycorrhizal colonization; the portions that showed the presence of mycorrhizal fungi were mounted on slides and examined at 100-400 X magnification to further analyse various mycorrhizal structures such as vesicles, arbuscules and hyphae structure. Percentage of mycorrhizal colonization in roots was estimated by:

$$
\% \text { Colonization }=\frac{\text { Total number of AM root segments }}{\text { Total number of root segments observed }} \times 100
$$

Spores of AM fungi were extracted and separated from the soil using wet sieving and decanting procedure Sieverding (1991). $100 \mathrm{ml}$ of DI water was added to dry equivalent of $50 \mathrm{~g}$ of soil from each site. It was then mixed vigorously to separate the spores from soil aggregates. The mixture was washed through a series of sieves $(2 \mathrm{~mm}, 100 \mu \mathrm{m}$ and $32 \mu \mathrm{m})$. Washing was done until the water flowing through the sieves was clear. The sievate retained on the sieves was washed and centrifuged 
with water to remove floating organic debris and the supernatant was discarded. The pellet in the bottom was re-suspended in a 50\% sucrose solution, and centrifuged for one minute at 2000 RPM to separate the spores from denser soil components. Immediately after centrifugation, spores in the sucrose supernatant were rinsed in a fine sieve to remove the sucrose. The spores were then washed into a filter paper for vacuum filtration. Spores were separated based on colour, size, type and morphology of the subtending hypha at the point of spore attachment were observed under a stereomicroscope at $100 \mathrm{x}$ and $400 \mathrm{x}$ magnification. The fungal spores were then mounted on slides for taxonomic identification to the genus level based on the spore morphology and wall characteristics, using the descriptions by the International Culture Collection of Arbuscular and Vesicular-Arbuscular Mycorrhizal Fungi (http:// invam.caf.wvu.edu).

The rhizosphere soil samples collected from the two farms were analysed for soil $\mathrm{pH}$, texture, soil moisture, total phosphorus $(\mathrm{P})$ and total carbon $(\mathrm{C})$ and nitrogen $(\mathrm{N})$. The soil $\mathrm{pH}$ was measured with a $\mathrm{pH}$ meter, (soil solution ratio 1:2 in water), texture was measured by the hydrometer method, percentage of carbon and nitrogen was measured with a TruSpec Carbon/Nitrogen Analyzer (Leco Corporation, St. Joseph, MI, USA). For total P measurement, soil samples ( $0.25 \mathrm{~g}$, finely ground) were ashed $\left(500^{\circ} \mathrm{C}\right)$, digested in $2 \mathrm{ml} \mathrm{HCL}(6 \mathrm{~N})$ and $10 \mathrm{ml} \mathrm{HNO}_{3}$, and analysed with an UV spectrophotometer (Shimadzu Scientific Instruments, Columbia, MD, USA. (U.S. Environmental Protection Agency [US EPA 1983]).

\section{Statistical analysis}

The relationship among AM spore density in rhizosphere, mycorrhizal root colonization and some soil parameters were determined by Pearson's correlation analysis. SAS was used for all statistical analyses (SAS Institute Inc. 1996).

\section{Results}

\section{Soil characteristics}

Physical, chemical and biological characteristics in organic farms in very important to determine soil productivity. Since many of the nutrients in organic farms should be transformed by microorganisms the soil in organic farms should be suitable for high microbial diversity and density. We analysed the rhizosphere soil samples under 31 plant species. The soil texture in both the farms was sandy loam. The soil $\mathrm{pH}$ was close to neutral to alkaline (soil $\mathrm{pH}$ : 7.19-8.33) which is common for south Florida with calcareous substrates. The soil moisture ranged between 6 and 29\%. The soil $\mathrm{C}$ concentration ranged between 4.99 and $20.4 \%$. The soil $\mathrm{N}$ concentration ranged between 0.02 and $0.94 \%$. The soil P concentration ranged between 0.03 and $4.96 \%$. It showed great differences among the rhizosphere soils. The means of physic-chemical soil properties are showed in Table 1.

\section{Mycorrhizal status in roots}

Among the 31-species analysed, 30 plant species showed mycorrhizal colonization (Table 1). AM colonization was not observed in roots of Spinacia oleracea. The colonization level ranged from 5\% - 75\%. The lowest was in Eruca sativa (5\%) followed by Chrysophyllum cainito (10\%). Highest colonization level was found in Cymbopogen nardus (75\%) followed by Juglans neotropicans and Vigna unguiculata (70\%).

\section{Spore density and diversity}

Sweitenia macrophylla was showed the highest number of AM spores per 50g soil during the study by values 535 spores, while Hibiscus acetosella was recorded as lowest plant associated with AM fungi by value 22 spores (Table 1). The mean number of AM spores at Possum Trot was 300 spores / 50g soil, while the mean number of AM spores at the Florida International University (FIU) was 84 spores / 50g soil. 
Table 1 Status of selected properties of the collected soil samples, the mean of number of AM spores and AM root colonization.

\begin{tabular}{|c|c|c|c|c|c|c|c|c|}
\hline & Plant Species & $\begin{array}{l}\mathbf{N} \\
(\%)\end{array}$ & $\begin{array}{c}\mathrm{C} \\
(\%)\end{array}$ & $\begin{array}{c}\mathbf{P} \\
(\boldsymbol{\%})\end{array}$ & pH & $\begin{array}{c}\text { Soil } \\
\text { Moisture } \\
(\%)\end{array}$ & $\begin{array}{c}\text { Spores } \\
\text { / 50g } \\
\text { Soil }\end{array}$ & $\begin{array}{c}\text { AM Root } \\
\text { Colonization } \\
(\%)\end{array}$ \\
\hline \multirow{21}{*}{ 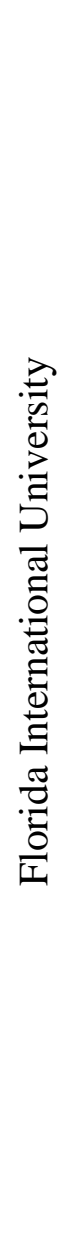 } & Hibiscus acetosella & 0.45 & 8.02 & 0.10 & 7.47 & 22.58 & 22 & 17 \\
\hline & Vigna unguiculata & 0.56 & 12.6 & 0.11 & 7.72 & 23.43 & 124 & 70 \\
\hline & Carica papaya & 0.64 & 11.1 & 0.11 & 7.59 & 24.86 & 96 & 63 \\
\hline & Musa paradisiaca & 0.27 & 5.17 & 0.05 & 7.68 & 10.28 & 76 & 35 \\
\hline & Ipomea batatas blackie & 0.52 & 8.31 & 0.14 & 7.35 & 5.83 & 48 & 15 \\
\hline & Capsicum chinense & 0.55 & 11.6 & 0.10 & 7.53 & 23.54 & 42 & 43 \\
\hline & Mentha piparita & 0.53 & 11.8 & 0.08 & 7.52 & 24.10 & 72 & 53 \\
\hline & Spinacia oleracea & 0.94 & 20.4 & 0.08 & 7.62 & 24.56 & 74 & 0 \\
\hline & Eruca sativa & 0.83 & 13.7 & 0.09 & 7.5 & 23.57 & 70 & 5 \\
\hline & Cucumis sativus & 0.90 & 18.5 & 0.10 & 7.48 & 24.04 & 70 & 25 \\
\hline & $\begin{array}{l}\text { Plectranthus } \\
\text { amboinicus }\end{array}$ & 0.79 & 16.3 & 0.09 & 7.61 & 22.60 & 62 & 65 \\
\hline & Psidium guajava & 0.26 & 4.99 & 0.03 & 7.59 & 7.89 & 100 & 45 \\
\hline & Persea americana & 0.37 & 8.05 & 0.08 & 7.5 & 23.54 & 40 & 65 \\
\hline & Jatropa curcas $L$ & 0.52 & 7.62 & 0.10 & 7.21 & 13.06 & 112 & 65 \\
\hline & Saccharum officinarum & 0.57 & 9.8 & 0.26 & 7.63 & 11.04 & 78 & 55 \\
\hline & Mangifera indica & 0.46 & 11.4 & 0.10 & 7.58 & 9.89 & 34 & 25 \\
\hline & Ipomoea batatas Poir & 0.68 & 12.3 & 0.20 & 7.48 & 18.52 & 82 & 45 \\
\hline & Cymbopogon citratus & 0.32 & 6.65 & 0.07 & 7.62 & 7.93 & 66 & 25 \\
\hline & Passiflora edulis & 0.44 & 13.3 & 0.08 & 7.76 & 23.64 & 78 & 25 \\
\hline & Cymbopogen nardus & 0.35 & 14.30 & 1.78 & 8.33 & 28.95 & 325 & 75 \\
\hline & Garcinia spicata & 0.42 & 15.33 & 1.25 & 8.19 & 21.80 & 95 & 15 \\
\hline \multirow{10}{*}{$\begin{array}{l}\overrightarrow{0} \\
\stackrel{0}{*} \\
\Xi \\
\Xi \\
\tilde{D} \\
0 \\
0\end{array}$} & Annona montana & 0.42 & 10.70 & 0.47 & 7.47 & 13.60 & 288 & 33 \\
\hline & Coffea arabica & 0.02 & 7.41 & 1.33 & 7.45 & 17.30 & 311 & 41 \\
\hline & Psychotria nervosa & 0.02 & 6.17 & 4.96 & 7.48 & 15.60 & 166 & 22 \\
\hline & $\begin{array}{l}\text { Lonchocorpus } \\
\text { punctalus }\end{array}$ & 0.28 & 11.00 & 0.59 & 7.41 & 15.00 & 272 & 40 \\
\hline & $\begin{array}{l}\text { Myrcirea califlora } \\
\text { jaboticaba }\end{array}$ & 0.12 & 10.50 & 0.98 & 7.52 & 18.56 & 134 & 11 \\
\hline & Tectona grandis (Teak) & 0.26 & 11.30 & 2.60 & 7.49 & 15.60 & 426 & 29 \\
\hline & Sweitenia macrophylla & 0.37 & 12.90 & 1.31 & 7.19 & 21.26 & 535 & 32 \\
\hline & Chrysophyllum cainito & 0.03 & 7.84 & 1.07 & 7.54 & 13.90 & 135 & 10 \\
\hline & Averrhoa carambola & 0.42 & 9.36 & 2.54 & 7.31 & 25.55 & 273 & 21 \\
\hline & Juglans neotropicans & 0.37 & 12.70 & 1.90 & 7.56 & 24.08 & 462 & 70 \\
\hline
\end{tabular}

Based on the morphology, Glomus was the dominant genus in both the sites followed by Gigaspora, Acaulospora and Scutellospora (Figure 1). There was no difference in the diversity of mycorrhizal fungi spores in both the sites. 
a)

c)

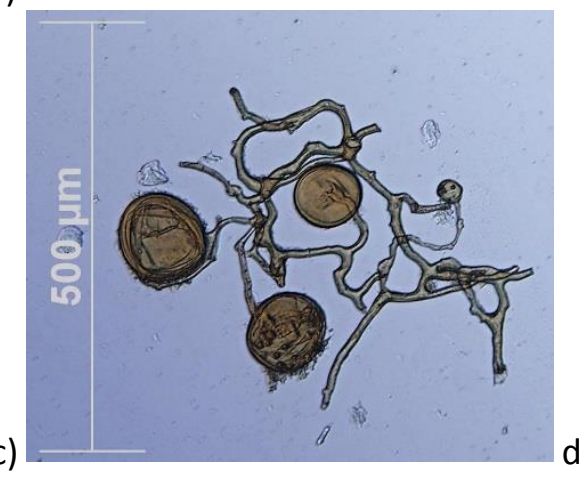

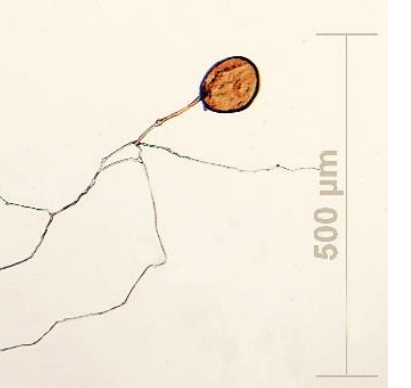

b)
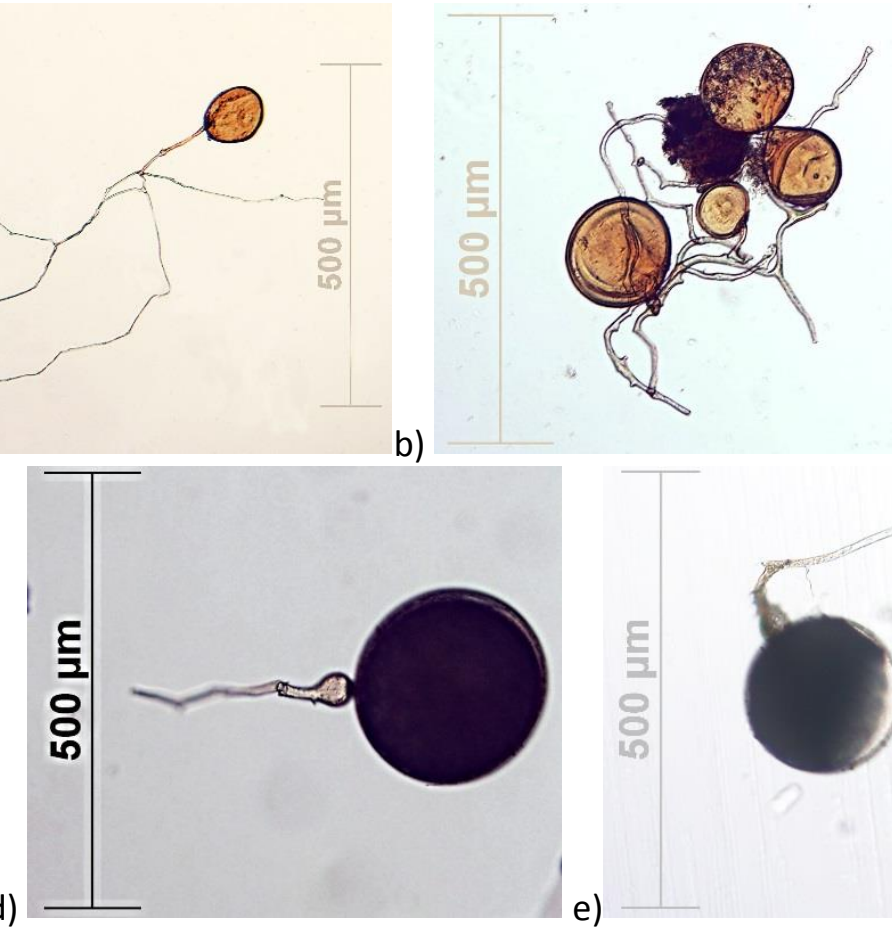

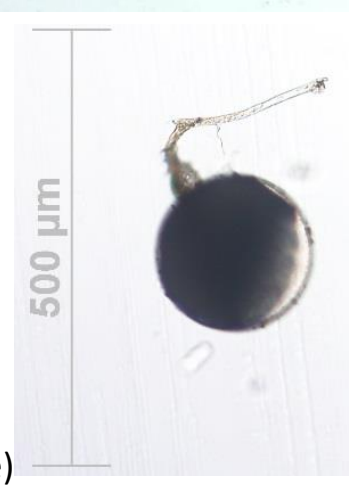

Figure 1 - Some spores of arbuscular mycorrhizal fungi: Glomus (a, b, c), Gigaspora (d), Scutellospora (e).

Correlation between AM spore density, root colonization and selected physico-chemical properties of soil are presented in Table 2. Correlation analysis demonstrated that AM spore density shows a negative correlation with soil $\mathrm{N}(\mathrm{P}<0.05)$, while it had a positive correlation with soil $\mathrm{P}(\mathrm{P}$ $<0.01)$. There was no correlation between the soil spore density and root colonization by AM fungi. The soil $\mathrm{N}$ had significant positive correlation with soil $\mathrm{C}(\mathrm{P}<0.0001)$ and also with moisture $(\mathrm{P}<$ 0.05), while it had significant negative correlation with soil $\mathrm{P}(\mathrm{P}<0.01)$. Furthermore, soil $\mathrm{C}$ had a significant positive correlation with moisture $(\mathrm{P}<0.001)$.

Table 2 Pearson correlation coefficients (r) for AM spore density, root colonization and selected physico-chemical properties of soil.

\begin{tabular}{lllllll}
\hline & $\mathbf{N}(\%)$ & $\mathbf{C}(\%)$ & $\mathbf{P}(\%)$ & $\mathbf{p H}$ & $\begin{array}{c}\text { Soil } \\
\text { Moisture (\%) }\end{array}$ & $\begin{array}{c}\text { Spores / } \\
\mathbf{5 0 g} \text { soil }\end{array}$ \\
\hline $\mathrm{C}(\%)$ & $0.70 * * * *$ & & & & & \\
$\mathrm{P}(\%)$ & $-0.54 * *$ & -0.15 & & & & \\
$\mathrm{pH}$ & 0.01 & 0.30 & 0.01 & & & \\
Soil & $0.37 *$ & $0.63 * * *$ & 0.09 & 0.27 & & \\
$\begin{array}{l}\text { Moisture (\%) } \\
\text { Spores / 50g soil }\end{array}$ & $-0.38 *$ & 0.04 & $0.56 * *$ & -0.12 & 0.14 & 0.17 \\
$\begin{array}{l}\text { AM root } \\
\text { colonization (\%) }\end{array}$ & 0.05 & -0.05 & -0.11 & 0.16 & 0.21 & \\
\hline
\end{tabular}

Significance levels are indicated by $* * * * \mathrm{P}<0.0001, * * * \mathrm{P}<0.001, * * \mathrm{P}<0.01, * \mathrm{P}<0.05$.

\section{Discussion}

This study presents the changes in root colonization, diversity and abundance of AM spores under various plants grown in organic farms located in Southern Florida. Clear changes were determined in the root colonization and abundance of AM spores, as well as some soil properties in the organic farms. Our results of high density of mycorrhizal fungi in organic farms are similar to the results reported by several researchers (Douds et al.1993, Kahiluoto \& Vestberg 1998, Oehl et al. 
2004). Spore density varied between the two farms. Possum Trot, which is dominantly a tropical fruit forest with several plant species in the shrub and herb layer had higher mycorrhizal spore density compared to the organically managed farm at FIU. Previous researchers have demonstrated that disturbance drastically reduces the mycorrhizal fungi spores (Medve 1984, Boddington \& Dodd 2000, Bever et al. 2001). Additionally, Possum Trot, a fruit forest with tropical plants, has higher species diversity compared to the FIU organic garden. The plants at FIU organic farm had higher degree of mycorrhizal colonization in the roots. The extent of AM colonization varied depending on the plant species. Many studies reported the presence of high levels of AM root colonization of plant grown in organic farming (Douds et al. 1995, Mäder et al. 2000, Ryan et al. 2004).

AM symbiosis is widespread throughout the plant kingdom, but some plants are nonmycorrhizal. In the organic farms, there are several non-mycorrhizal plants of 31 species, such as Spinacia oleracea, Eruca sativa and Chrysophyllum cainito. AM colonization was not observed in roots of Spinacia oleracea. Eruca sativa and Chrysophyllum cainito are generally reported as nonhost species (Giovannetti et al. 1993), in our study, we found a low degree of mycorrhizal colonization (5\% and $10 \%$ respectively). Thus, the mycorrhizal fungi relationship of these plants needs further exploration. However, there are several studies reporting mycorrhizal colonization in non-host species (Veiga et al. 2013).

Past studies in mycorrhizal spore diversity and disturbance have shown mixed results (Pagano \& Scotti 2009, Purin et al. 2006). In our study, there was no difference in the diversity of mycorrhizal fungi spores in both the sites, disturbed and not disturbed. Both sites had Glomus, Gigaspora, Acaulospora and Scutellospora genus, but Glomus was the dominant one. This result was as expected since Glomus has been reported as the widest spread mycorrhizal fungi in Florida (Fisher \& Jayachandran 1999, Rasmann et al. 2009, Scharnagl 2013).

As we found, similar results were reported by Priyadharsini et al. (2012) and Karthigairaj and Kalaiarasu (2015) who found that soil N negatively influence the number of AM spores and by Rathore and Singh (1995) who found that soil P positively influence the number of AM spores. Correlation did not determine between the soil spore density and root colonization by AM fungi. Similar results have been reported earlier studies (Zhao et al. 2001). While further study to analyse the mycorrhizal dynamics in organically managed farms is needed, our results indicate that disturbance did not have much impact on the mycorrhizal colonization in the roots but did have an impact on the rhizosphere spore proliferation. Additionally, there was no visible difference in the spore diversity in two sites.

\section{References}

Bennett AE, Bever JD, Bowers MD. 2009 - Arbuscular mycorrhizal fungal species suppress inducible plant responses and alter defensive strategies following herbivory. Oecologia 160, 771-779.

Bever JD, Schultz PA, Pringle A, Morton JB. 2001 - Arbuscular mycorrhizal fungi: more diverse than meets the eye, and the ecological tale of why the high diversity of ecologically distinct species of arbuscular mycorrhizal fungi within a single community has broad implications for plant ecology. BioScience 51, 923-932.

Boddington CL, Dodd JC. 2000 - The effect of agricultural practices on the development of indigenous arbuscular mycorrhizal fungi. I. Field studies in an Indonesian ultisol. Plant and Soil 218, 137-144.

Brundrett M. 1991 - Mycorrhizas in natural ecosystems. Advance in ecological research 21, 171313.

Clark RB, Zeto SK. 2000 - Mineral acquisition by arbuscular mycorrhizal plants. Journal of Plant Nutrition 23, 867-902.

Daisog H, Sbrana C, Cristani C, Moonen AC et al. 2012 - Arbuscular mycorrhizal fungi shift competitive relationships among crop and weed species. Plant and Soil 353, 395-408. 
Douds DD, Janke RR, Peters SE. 1993 - VAM fungus spore populations and colonization of roots of maize and soybean under conventional and low-input sustainable agriculture. Agriculture, Ecosystems \& Environment 43, 325-335.

Douds DD, Galvez L, Janke RR, Wagoner P. 1995 - Effect of tillage and farming system upon populations and distribution of vesicular-arbuscular mycorrhizal fungi. Agriculture, Ecosystems \& Environment 52, 111-118.

Fisher JB, Jayachandran K. 1999 - Root structure and arbuscular mycorrhizal colonization of the palm Serenoa repens under field conditions. Plant and Soil 217, 229-241.

Giovannetti M, Sbrana C, Avio L, Citernesi AS et al. 1993 - Differential hyphal morphogenesis in arbuscular mycorrhizal fungi during pre-infection stages. New Phytologist 125, 587-593.

Kahiluoto H, Vestberg M. 1998 - The effect of arbuscular mycorrhiza on biomass production and phosphorus uptake from sparingly soluble sources by leek (Allium porrum L.) in Finnish field soils. Biological Agriculture \& Horticulture 16, 65-85.

Karthigairaj M, Kalaiarasu S. 2015 - Biodiversity of Am Fungi In The Cassava Grown Soils Of Semiarid Tropics of Tamilnadu. Asian Journal of Science and Technology 6, 1815-1818.

Lee EH, Eo JK, Ka KH, Eom AH. 2013 - Diversity of arbuscular mycorrhizal fungi and their roles in ecosystems. Mycobiology 41, 121-125.

Lendzemo VW, Kuyper TW, Kropff MJ, van Ast AV. 2005 - Field inoculation with arbuscular mycorrhizal fungi reduces Striga hermonthica performance on cereal crops and has the potential to contribute to integrated Striga management. Field Crops Research 91, 51-61.

Mäder P, Edenhofer S, Boller T, Wiemken A et al. 2000 - Arbuscular mycorrhizae in a long-term field trial comparing low-input (organic, biological) and high-input (conventional) farming systems in a crop rotation. Biology and Fertility of Soils 31, 150-156.

Marschner H, Dell B. 1994 - Nutrient uptake in mycorrhizal symbiosis. Plant and soil 159, 89-102.

McGonigle TP, Miller MH, Evans DG, Fairchild GL et al. 1990 - A new method which gives an objective measure of colonization of roots by vesicular-arbuscular mycorrhizal fungi. New phytologist $115,495-501$.

Medve RJ. 1984 - The mycorrhizae of pioneer species in disturbed ecosystems in western Pennsylvania. American Journal of Botany 71, 787-794.

Nelson NO, Janke RR. 2007 - Phosphorus sources and management in organic production systems. HortTechnology 17, 442-454.

Oehl F, Sieverding E, Mäder P, Dubois D et al. 2004 - Impact of long-term conventional and organic farming on the diversity of arbuscular mycorrhizal fungi. Oecologia 138, 574-583.

Paszkowski U. 2006 - A journey through signaling in arbuscular mycorrhizal symbioses 2006. New Phytologist 172, 35-46.

Pagano MC, Scotti MR. 2009 - A survey of the arbuscular mycorrhiza occurrence in Paepalanthus bromelioides and Bulbostylis sp. in rupestrian fields, Brazil. Micologia Aplicada Internacional $21,1-10$.

Priyadharsini P, Pandey R, Muthukumar T. 2012 - Arbuscular mycorrhizal and dark septate fungal associations in shallot (Allium cepa L. var. aggregatum) under conventional agriculture. Acta Botanica Croatica 71, 159-175.

Purin S, Klauberg Filho O, Stürmer SL. 2006 - Mycorrhizae activity and diversity in conventional and organic apple orchards from Brazil. Soil Biology and Biochemistry 38, 1831-1839.

Rasmann C, Graham JH, Chellemi DO, Datnoff LE et al. 2009 - Resilient populations of root fungi occur within five tomato production systems in southeast Florida. Applied Soil Ecology 43, $22-31$.

Rathore VP, Singh HP. 1995 - Quantification and correlation of vesicular-arbuscular mycorrhizal propagules with soil properties of some mollisols of northern India. Mycorrhiza 5, 201-203.

Ryan MH, Derrick JW, Dann PR. 2004 - Grain mineral concentrations and yield of wheat grown under organic and conventional management. Journal of the Science of Food and Agriculture 84, 207-216. 
SAS Institute, Inc., 1996 - SAS/STAT user's guide, version 6.12. SAS Institute, Inc., Cary, North Carolina.

Scharnagl K. 2013 - The effects of arbuscular mycorrhizal fungi on four legume hosts in south Florida pine rockland soils. FIU Electronic Theses and Dissertations.

Sieverding E. 1991 - Vesicular-arbuscular mycorrhiza management in tropical agrosystems. GTZ.

Smith SE, Read DJ. 1997 - Mycorrhizal Symbiosis. Ed 2, Academic Press, London.

Smith SE, Read DJ. 2008 - Mycorrhizal Symbiosis. Ed 3, Academic Press, San Diego.

Soti PG, Jayachandran K, Koptur S, Volin JC. 2015 - Effect of soil pH on growth, nutrient uptake, and mycorrhizal colonization in exotic invasive Lygodium microphyllum. Plant Ecology 216, 989-998.

Veiga RS, Faccio A, Genre A, Pieterse CM et al. 2013 - Arbuscular mycorrhizal fungi reduce growth and infect roots of the non-host plant Arabidopsis thaliana. Plant, Cell \& Environment 36, $1926-1937$.

Wilson GW, Rice CW, Rillig MC, Springer A et al. 2009 - Soil aggregation and carbon sequestration are tightly correlated with the abundance of arbuscular mycorrhizal fungi: results from longterm field experiments. Ecology Letters 12, 452-461.

Zhao ZW, Xia YM, Qin XZ, Li XW et al. 2001- Arbuscular mycorrhizal status of plants and the spore density of arbuscular mycorrhizal fungi in the tropical rain forest of Xishuangbanna, southwest China. Mycorrhiza 11, 159-162. 